\title{
Milk production and concentrations of blood metabolites as influenced by the level of wet distiller's solubles in dairy cows receiving grass silage-based diet
}

\author{
PekKa Huhtanen and Harri Miettinen \\ Huhtanen, P. \& Miettinen, H. 1992. Milk production and concentrations of blood \\ metabolites as influenced by the level of wet distiller's solubles in dairy cows \\ receiving grass silage-based diet. Agric. Sci. Finl. 1:279-290. (Univ. Helsinki, Dept. \\ Anim. Sci., SF-00710 Helsinki, Finland, Valio, Finnish Co-op. Dairies' Association, \\ R \& D Centre, P.O. Box 176, SF-00181 Helsinki, Finland.)
}

Twelve Finnish Ayrshire cows were used in a 4 x 4 Latin square design with 4-week experimental periods to study the effects of replacing increasing amount of barley with wet distiller's solubles (WDS) on feed intake, milk production, digestibility and blood constituents. The four dietary treatments consisted of grass silage ad libitum and $7.8 \mathrm{~kg}$ dry matter (DM)/d of barley, of which 0 (WDS0), 1 (WDS1), 2 (WDS2) and $3 \mathrm{~kg}$ $\mathrm{DM} / \mathrm{d}$ (WDS3) was replaced with WDS. Mainly because of a greater intake of concentrate with WDS containing diets silage DM intake varied quadratically $(\mathrm{P}<0.05)$ with increasing level of WDS with a minimum being observed with diet WDS1. The total DM intake $(\mathrm{P}<0.05)$, milk yield $(\mathrm{P}<0.05)$ and lactose yield $(\mathrm{P}<0.01)$ increased linearly with the level of WDS. Milk protein yield varied both linearly $(\mathrm{P}<0.05)$ and quadratically $(\mathrm{P}<0.05)$ with the level of WDS reaching a maximum with diet WDS2. WDS had no significant effect on milk fat or protein content but lactose content increased $(\mathrm{P}<0.001)$ with the level of WDS. The effects of the treatments on digestibility of dietary constituents were generally small, although in certain cases significant. Replacing barley with WDS increased linearly the plasma concentrations of butyrate $(\mathrm{P}<0.10)$, glucose $(\mathrm{P}<0.10)$, non-esterified fatty acids $(\mathrm{NEFA})(\mathrm{P}<0.05)$, and urea $(\mathrm{P}<0.001)$. Inclusion of WDS in the diet increased the postprandial peaks of plasma propionate, butyrate, insulin and urea, and decreased that of ketones (acetoacetate and betahydroxybutyrate). Based on the effects of WDS on the mean plasma concentrations and postprandial pattern of changes in the blood and plasma metabolites, it is concluded that feeding WDS as a replacement of barley most likely increased hepatic gluconeogenesis and urea synthesis. This conclusion is supported by the changes in the milk composition and in the relative yields of milk constituents with increasing rate of WDS inclusion.

Key words: silage, distiller's solubles, milk production, blood metabolites

\section{Introduction}

Distiller's solubles, a by-product from the integrated starch-ethanol process (NÄSI 1988) are mainly used as a protein source for dairy cattle. Increasing di- etary crude protein $(\mathrm{CP})$ concentration by including dried distiller's solubles (DDS) in a grass silagebased diet had no effect on milk yield or milk composition (AlA-SEPPÄLÄ et al. 1988). In contrast, increasing protein content in the supplement by 
including soybean meal or fish meal has consistently increased milk yield in cows given grass silage ad libitum (ThOMAS and RAE 1988; ChAMBERLAIN et al. 1989). Therefore, the absence of production response to DDS suggests that the diets were limited in the supply of protein, probably because of a high proportion of rumen degradable $\mathrm{N}$ in the DDS. This is supported by the fact that replacing barley or barley fibre with untreated wet distiller's solubles (WDS) had no effect on duodenal non-ammonia N flow in cattle (HUHTANEN 1992). In the following study, a treatment of DDS with a formaldehyde reagent tended to increase milk and milk protein yield as compared with untreated DDS (HUHTANEN et al. 1991), and the performance of the cows given treated DDS was similar to that observed with isonitrogenous rapeseed meal supplementation.

In commercial farming, distiller's solubles are used mainly in wet form to avoid expensive drying procedures. In addition to high CP content (approximately $300 \mathrm{~g} / \mathrm{kg} \mathrm{DM}$ ), WDS also contain about 150 and $50 \mathrm{~g} / \mathrm{kg} \mathrm{DM}$ of lactic acid and glycerol. Feeding WDS diets to cattle increased molar proportions of propionate mainly at the expense of acetate in the rumen fluid (HuHTANEN 1992). The changes in the rumen volatile fatty acids (VFA) are most probably due to fermentation of lactate to propionate (CHAMBerLain et al. 1983; NewBold et al. 1986; JAAKKOLA and HuHTANEN 1989; 1992). Substituting barley with treated WDS can thus increase the supply of substrates, propionate from the rumen and amino acids from the small intestine, available for hepatic gluconeogenesis. Increased hepatic glucose production increases plasma glucose concentration (ANNISON et al. 1974) which in turn can increase lactose and milk production. Increased plasma propionate and glucose levels can stimulate insulin release (BINES and HART 1984; JENNY and POLAN 1975), and according to the glucogenic theory of MCCLYMONT and VALLANCE (1962), this can lead to a decline in milk fat content. In previous studies (HUHTANEN et al. 1992), changing the ratio of glucogenic (propionate) to nonglucogenic (acetate and butyrate) VFA has been shown to affect both the composition of blood and milk.

The purpose of this study was to evaluate the effects of WDS in the silage-based diet on feed intake, milk production and digestibility in dairy cows. Blood metabolites were determined to assess the possible effects of WDS on nutrient supply in more detail.

\section{Material and methods}

\section{Animal production study}

Twelve (6 primiparous and 6 multiparous) Finnish Ayrshire autumn calving cows were used in a balanced 4 x 4 Latin square experiment. Each experimental period was of 4 weeks duration. The cows were divided into three blocks of four cows so that each group was as similar as possible in milk yield during the week before the start of the experiment and parity. Within each block, the cows were allocated at random to treatment sequences. The four treatments consisted of grass silage ad libitum and barley $(7.8 \mathrm{~kg} \mathrm{DM} / \mathrm{d})$ of which $0,1,2$ or $3 \mathrm{~kg}$ $\mathrm{DM} / \mathrm{d}$ was replaced with WDS. The treatments are shown in Table 1.

At the start of the experiment, the mean number of days after calving was 44 (SE 5.0) and milk yield $27.9 \mathrm{~kg} / \mathrm{d}$ (SE 1.58). The animals were housed and milked in individual stalls throughout the experiment. Grass silage was offered twice daily in sufficient quantities to allow proportional refusal of $0.05-0.10$. The supplements were given in two equal meals at 6.00 and 14.00 hours on a flat-rate basis throughout the experimental period. The cows were changed to a new dietary treatment within four days.

\section{Food}

Direct-cut silage was made from a primary growth timothy-meadow fescue sward. The herbage was harvested with a precision-chop forage harvester and ensiled in a clamp silo. Formic acid $(800 \mathrm{~g} / \mathrm{kg}$, AIV II) was applied during ensiling with the rate being $4-51 / t$. 
Table 1. Dietary treatments.

Treatment

\begin{tabular}{lrrrr}
\cline { 2 - 5 } & WDS0 & WDS1 & WDS2 & WDS3 \\
\hline Silage & ad lib & ad lib & ad lib & ad lib \\
Barley (kg DM/d) & 7.80 & 6.80 & 5.80 & 4.80 \\
WDS (kg DM/d) & - & 1.00 & 2.00 & 3.00 \\
Mineral A' $(\mathrm{kg} / \mathrm{d})$ & 0.25 & 0.17 & 0.08 & - \\
Mineral B' $(\mathrm{kg} / \mathrm{d})$ & - & 0.08 & 0.17 & 0.25 \\
\hline
\end{tabular}

${ }^{1} \mathrm{Ca}: \mathrm{P} 2.1$

${ }^{2} \mathrm{Ca}: \mathrm{P} 6.7$

WDS obtained from the integrated starch-ethanol process (NÄSı 1988) was treated with a formaldehyde reagent (European Patent Office, 1982) to reduce ruminal degradability of crude protein. To ensure the preservation of WDS over a 2-week storage period, benzoic acid was applied at the rate of $1 \mathrm{~kg} / \mathrm{t}$. To balance different the calcium and phosphorus content of barley and WDS, the mineral mixture given with barley (Ca:P 2.1) was gradually replaced with a mixture in which the $\mathrm{Ca}: \mathrm{P}$ ratio was 6.7. Before feeding, WDS was mixed with rolled barley.

\section{Measurements and recordings}

The final two weeks of each period was used for recording purposes. Silage samples were taken twice a week for $\mathrm{pH}$ and oven DM determination and samples dried at $60{ }^{\circ} \mathrm{C}$ were bulked over one period. Fresh silage samples were frozen for ammonia, lactic acid and volatile fatty acid (VFA) analyses. Samples of barley and WDS were taken daily and bulked over one period to provide a sample for each period. WDS samples were stored as frozen.

Milk yields of individual animals were recorded daily and samples for fat, protein and lactose analyses, in proportion to yield, were taken on days 20 , 21,26 and 27 of each period.. Live weights were recorded at biweekly intervals before the afternoon feeding on two consecutive days. Live weight change was calculated as a linear regression of live weight and time.

\section{Ration digestibility and energy utilization}

Apparent digestibility of the diets was determined using acid insoluble ash (AIA) as an internal marker (VAN KeULEN and Young 1977). The four high producing cows in the first block were used in digestibility study. Faecal grab samples were taken during the last week of each experimental period on 5 consecutive days at 7.00 and $16.00 \mathrm{~h}$.

ME intake was calculated according to MAFF (1984) and as 0.82 x DE intake (ARC 1980). Milk energy content was calculated from the equations of TYRREL and REID (1965). The energy requirements for maintenance and live weight change were calculated according to MAFF (1984). The utilization of ME for milk production was calculated both ignoring $\left(\mathrm{k}_{1}\right)$ or including $\left(\mathrm{k}_{10}\right)$ the effect of live weight change.

\section{Blood sampling}

The two blocks of the cows which had the highest milk yield before the experiment were used for blood sampling. Ten blood samples at hourly intervals were taken via an indwelling jugular vein catheter (Cava-Fix, B. Braun Melsungen AG, 1.2$2.1 / \mathrm{G} 14,70 \mathrm{~cm}$ ) on the last day of each experimental period starting before the afternoon feeding. The cows were catheterised on the day before sampling.

\section{Chemical analyses}

Chemical analyses and calculation of feeding values were made as described by HUHTANEN et al. (1988). Fresh samples of WDS were used for analyses. Gross energy (GE) content of the feed and faecal samples was determined by an adiabatic bomb calorimeter (Parr 1108). The chemical composition and calculated feeding values of the experimental feeds are presented in Table 2. Milk fat, protein and lactose contents were analyzed by an infra-red milk analyzer. Milk urea concentration was analysed according to RAJAMÄKI and RAURAMAA (1984) and acetone according to RAJAMÄKI and RAURAMAA (1985). B-hydroxybutyrate (BHB) 
and acetoacetate were analysed from the whole blood and glucose, non-esterified fatty acids (NEFA), insulin, urea and VFA were analyzed from the plasma. NEFA were analysed from the samples taken before feeding and 2, 4, 6 and 8 hours after feeding. The methods of the blood analyses are described in detail by MIETTINEN and Huntanen (1989). Different from the previous experiment, plasma glucose was analysed enzymatically using commercial reagents (BioMeriux, France). The plasma VFA were measured by head space gas chromatography.

\section{Statistical analyses}

The model used to analyze feed intake and animal production data was:

$\mathrm{Y}_{\mathrm{ijklm}}=\mathrm{S}_{\mathrm{i}}+\mathrm{C}_{\mathrm{j}}\left(\mathrm{S}_{\mathrm{i}}\right)+\mathrm{P}_{\mathrm{k}}+\mathrm{T}_{1}+(\mathrm{SP})_{\mathrm{ik}}+(\mathrm{ST})_{\mathrm{il}}+\mathrm{e}_{\mathrm{ijklm}}$, where $\mathrm{S}, \mathrm{C}, \mathrm{P}$ and $\mathrm{T}$ are square, cow, period and treatment effects. The data from the digestibility study was analysed by the analyses of variance for

Table 2. Chemical composition and feeding values of the experimental feeds.

\begin{tabular}{lrrr}
\hline & Silage & Barley & WDS \\
\hline Dry matter $(\mathrm{g} / \mathrm{kg})$ & 207 & 871 & 366 \\
In dry matter $(\mathrm{g} / \mathrm{kg})$ & & & \\
$\quad$ Ash & 75 & 22 & 136 \\
Crude protein & 154 & 132 & 293 \\
Ether extract & 54 & 35 & 65 \\
Crude fibre & 269 & 49 & 9 \\
NFE & 448 & 765 & 495 \\
NDF & 525 & 192 & 10 \\
ADF & 287 & 53 & 6 \\
ADL & 18 & 9 & 7 \\
& & & \\
GE (MJ/kg DM) & 19.3 & 18.8 & 19.5 \\
Feed values & & & \\
FU $/ \mathrm{kg} \mathrm{DM}$ & 0.75 & 1.18 & 1.02 \\
$\mathrm{ME}(\mathrm{MJ} / \mathrm{kg} \mathrm{DM})_{\text {DCP }^{3} \mathrm{~g} / \mathrm{kg} \mathrm{DM}}^{10.6}$ & 13.8 & 12.6 \\
\hline
\end{tabular}

${ }^{1} \mathrm{NFE}=$ nitrogen free extractives, ${ }^{2} \mathrm{FU}=$ fattening feed unit, ${ }^{3} \mathrm{DCP}=$ digestible crude protein. In silage: $\mathrm{pH} 3.73$; in DM $(\mathrm{g} / \mathrm{kg})$ : water soluble carbohydrates 32 , lactic acid 48 , acetic acid 16, butyric acid 0.5 ; in total nitrogen $(\mathrm{g} / \mathrm{kg})$ : ammonia N 27, soluble N 580 .
Latin square experiments. The data from blood analyses was analysed by slit-plot analyses of variance (SNEDECOR and COCHRAN 1967) using the following model:

$\mathrm{Y}_{\mathrm{ijk} k \mathrm{mn}}=\mathrm{C}_{\mathrm{i}}+\mathrm{P}_{\mathrm{j}}+\mathrm{T}_{\mathrm{k}}+\mathrm{e}_{\mathrm{ijkl}}+\mathrm{H}_{\mathrm{m}}+(\mathrm{HC})_{\mathrm{im}}+(\mathrm{HP})_{\mathrm{jm}}+$ $(\mathrm{HT})_{\mathrm{km}}+\mathrm{e}_{\mathrm{ijklmn}}$, where $\mathrm{C}, \mathrm{P}, \mathrm{T}$ and $\mathrm{H}$ are the effects of cow, period, treatment and sampling time. The sums of squares of treatment effects were further partitioned using polynomial contrasts into linear, quadratic and cubic effects of the level of WDS in the diet. The sums of squares of the $\mathrm{H} \mathrm{x} \mathrm{T}$ interaction were divided into the following contrasts: WDS linear $\times \mathrm{H}(9 \mathrm{df})$, WDS quadratic $\times \mathrm{H}(9 \mathrm{df})$ and WDS cubic $\times \mathrm{H}(9 \mathrm{df})$.

\section{Results}

\section{Feed intake and nutrient supply}

Including WDS in the diet increased the concentrate DM intake (Table 3). Mainly because of the differences in concentrate intake, silage DM intake varied quadratically $(\mathrm{P}<0.05)$ with a minimum in cows given diet WDS1. Total DM intake $(\mathrm{P}<0.05)$ and calculated intake of $\mathrm{ME}(\mathrm{P}<0.10)$ and $\mathrm{DCP}$ $(\mathrm{P}<0.001)$ increased linearly with the level of WDS. A quadratic $(\mathrm{P}<0.05)$ response to WDS was noted for calculated FU intake. With increasing level of WDS, dietary CP concentration increased from 146 (diet WDS0) to $172 \mathrm{~g} / \mathrm{kg}$ DM (diet WDS3) with a respective of NDF from 392 to 348 $\mathrm{g} / \mathrm{kg}$ DM.

\section{Digestibility}

The differences between the treatments in the digestibility of dietary constituents were small, although in some cases statistically significant (Table 4).

\section{Milk yield and milk composition}

The yield and composition of milk and the yield of milk constituents for cows receiving the experimental diets are shown in Table 5. A linear increase 
Table 3. Feed intake and estimated nutrient consumption for cows given the experimental diets.

\begin{tabular}{|c|c|c|c|c|c|c|c|c|}
\hline & \multicolumn{4}{|c|}{ Treatment } & \multirow{2}{*}{ SEM } & \multicolumn{3}{|c|}{ Significance of effect } \\
\hline & WDS0 & WDS1 & WDS2 & WDS3 & & Linear & Quadr. & Cubic \\
\hline \multicolumn{9}{|c|}{ Feed intake (kg DM/d) } \\
\hline Silage & 9.90 & 9.14 & 9.53 & 9.70 & 0.168 & NS & * & NS \\
\hline Concentrate & 6.51 & 7.74 & 7.54 & 7.45 & - & & & \\
\hline Total & 16.41 & 16.88 & 17.11 & 17.15 & 0.190 & * & NS & NS \\
\hline $\mathrm{FU} / \mathrm{d}$ & 15.14 & 15.85 & 15.81 & 15.63 & 0.177 & NS & * & NS \\
\hline $\mathrm{ME}(\mathrm{MJ} / \mathrm{d})$ & 194.9 & 202.6 & 203.4 & 202.3 & 2.32 & o & NS & NS \\
\hline $\operatorname{DCP}(g / d)$ & 1748 & 1924 & 2060 & 2233 & 24.4 & ${ }^{* * *}$ & NS & NS \\
\hline
\end{tabular}

SEM = standard error of means

Significance: o $(\mathrm{P}<0.10) ;{ }^{*}(\mathrm{P}<0.05) ;{ }^{* *}(\mathrm{P}<0.01) ;{ }^{* * *}(\mathrm{P}<0.001)$

Table 4. Digestibility of dietary constituents by the cows given the experimental diets.

\begin{tabular}{|c|c|c|c|c|c|c|c|c|}
\hline & \multicolumn{4}{|c|}{ Treatment } & \multirow{2}{*}{ SEM } & \multicolumn{3}{|c|}{ Significance of effect } \\
\hline & WDS0 & WDS1 & WDS2 & WDS3 & & Linear & Quadr. & Cubic \\
\hline Organic matter & 0.779 & 0.771 & 0.787 & 0.785 & 0.0036 & NS & NS & NS \\
\hline Crude protein & 0.716 & 0.700 & 0.719 & 0.720 & 0.0049 & NS & NS & NS \\
\hline Ether extract & 0.660 & 0.658 & 0.685 & 0.691 & 0.0066 & ** & NS & NS \\
\hline Crude fibre & 0.713 & 0.713 & 0.720 & 0.722 & 0.0030 & * & NS & NS \\
\hline $\mathrm{NFE}^{\prime}$ & 0.827 & 0.818 & 0.837 & 0.834 & 0.0039 & NS & NS & * \\
\hline $\mathrm{NDF}^{2}$ & 0.731 & 0.734 & 0.743 & 0.739 & 0.0038 & NS & NS & NS \\
\hline Cellulose & 0.781 & 0.783 & 0.796 & 0.795 & 0.0026 & ** & NS & NS \\
\hline Hemicellulose & 0.719 & 0.723 & 0.731 & 0.718 & 0.0049 & NS & NS & NS \\
\hline Gross energy & 0.752 & 0.752 & 0.764 & 0.764 & 0.0059 & NS & NS & NS \\
\hline
\end{tabular}

${ }^{1}$ Nitrogen free extractives

${ }^{2}$ Neutral detergent fibre

For significance: see Table 3

$(\mathrm{P}<0.05)$ in response to WDS was observed for milk yield, but the effect tended to level out with the lowest level of WDS. Milk fat content decreased slightly $(\mathrm{P}>0.10)$ with the level of WDS, and as a result, yields of fat and fat corrected milk (FCM) were not changed. Both the linear and quadratic response to WDS in milk protein yield were significant $(\mathrm{P}<0.05)$ with a maximum obtained with diet WDS2. As the increase in milk yield was associated with a linear increase $(\mathrm{P}<0.001)$ in lactose content, there was a linear $(\mathrm{P}<0.01)$ increase in lactose yield with the level of WDS. Milk urea concentration increased linearly $(\mathrm{P}<0.001)$ and quadratically $(\mathrm{P}<0.01)$ while milk acetone content tended to decrease with the level of WDS. No significant square $\mathrm{x}$ treatment interactions were observed, but the response to WDS tended to be slightly greater in high yielding cows.

Mean live weight or live weight change were not significantly affected by the treatments.

\section{Utilization of ME}

The efficiency of the utilization of ME for milk production decreased with the level of WDS in the diet (Table 6). The difference was greater when the 
Table 5. Yields of milk and milk constituents, milk composition, live weight and feed conversion for cows given the experimental diets.

\begin{tabular}{|c|c|c|c|c|c|c|c|c|}
\hline & \multicolumn{4}{|c|}{ Treatment } & \multirow{2}{*}{ SEM } & \multicolumn{3}{|c|}{ Significance of effect } \\
\hline & WDS0 & WDS1 & WDS2 & WDS3 & & Linear & Quadr. & Cubic \\
\hline Milk yield (kg/d) & 23.6 & 24.5 & 24.4 & 24.4 & 0.25 & $*$ & NS & NS \\
\hline $\mathrm{FCM}$ yield $(\mathrm{kg} / \mathrm{d})$ & 25.4 & 25.8 & 25.8 & 25.8 & 0.27 & NS & NS & NS \\
\hline \multicolumn{9}{|l|}{ Milk composition $(\mathrm{g} / \mathrm{kg})$} \\
\hline Fat & 45.4 & 44.7 & 44.4 & 44.2 & 0.66 & NS & NS & NS \\
\hline Protein & 32.6 & 32.6 & 32.9 & 32.2 & 0.30 & NS & NS & NS \\
\hline Lactose & 46.8 & 47.3 & 47.5 & 47.8 & 0.12 & $* * *$ & NS & NS \\
\hline \multicolumn{9}{|l|}{ Yield (g/d) } \\
\hline Fat & 1060 & 1070 & 1067 & 1068 & 15.0 & NS & NS & NS \\
\hline Protein & 769 & 785 & 797 & 784 & 6.1 & $*$ & $*$ & NS \\
\hline Lactose & 1104 & 1151 & 1154 & 1168 & 12.8 & $* *$ & NS & NS \\
\hline Milk urea (mmol/1) & 3.15 & 3.10 & 3.46 & 3.86 & 0.045 & $* * *$ & $* *$ & NS \\
\hline Milk acetone $(\mathrm{mmol} / \mathrm{l})$ & 0.066 & 0.059 & 0.059 & 0.057 & 0.0066 & NS & NS & NS \\
\hline \multicolumn{9}{|l|}{ Live weight } \\
\hline Mean (kg) & 529 & 530 & 526 & 527 & 1.7 & NS & NS & NS \\
\hline Change (kg/d) & 0.05 & 0.07 & -0.09 & -0.16 & 0.101 & NS & NS & NS \\
\hline \multicolumn{9}{|l|}{ Feed conversion } \\
\hline (FU/kg FCM) & 0.430 & 0.448 & 0.461 & 0.462 & 0.0120 & o & NS & NS \\
\hline
\end{tabular}

For significance: see Table 3

Table 6. Calculated efficiency of the utilization of ME for milk production in the cows given the experimental diets.

\begin{tabular}{|c|c|c|c|c|c|c|c|c|}
\hline & \multicolumn{4}{|c|}{ Treatment } & \multirow{2}{*}{ SEM } & \multicolumn{3}{|c|}{ Significance of effect } \\
\hline & WDS0 & WDS1 & WDS2 & WDS3 & & Linear & Quadr. & Cubic \\
\hline ME intake $(\mathrm{MJ} / \mathrm{d})^{1}$ & 194.9 & 202.6 & 203.4 & 202.2 & 2.52 & o & NS & NS \\
\hline $\mathrm{ME}$ intake $(\mathrm{MJ} / \mathrm{d})^{2}$ & 189.2 & 196.8 & 204.1 & 202.2 & 2.40 & $* * *$ & NS & NS \\
\hline \multicolumn{9}{|l|}{ ME requirement $(\mathrm{MJ} / \mathrm{d})$} \\
\hline Maintenance & 50.1 & 50.2 & 49.9 & 50.0 & 0.12 & NS & NS & NS \\
\hline 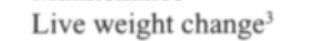 & 2.8 & 2.9 & -2.0 & -4.1 & 3.15 & o & NS & NS \\
\hline Milk energy yield $(\mathrm{MJ} / \mathrm{d})$ & 77.2 & 78.9 & 79.1 & 79.1 & 0.94 & NS & NS & NS \\
\hline \multicolumn{9}{|l|}{ Efficiency } \\
\hline Including LW change ${ }^{1}$ & 0.545 & 0.528 & 0.510 & 0.509 & 0.0124 & * & NS & NS \\
\hline Ignoring LW change ${ }^{1}$ & 0.533 & 0.517 & 0.517 & 0.520 & 0.0092 & NS & NS & NS \\
\hline
\end{tabular}

${ }^{1}$ Calculated according to MAFF (1984)

${ }^{2}$ Calculated as $0.82 \times$ DE intake

${ }^{3}$ Allowing $28 \mathrm{MJ}$ for each $\mathrm{kg}$ lost and subtracting $34 \mathrm{MJ}$ for each $\mathrm{kg}$ gained

For significance: see Table 3. 
effect of LW change was taken into account $\left(\mathrm{k}_{10}\right)$ than when the effect of LW change was ignored $\left(k_{1}\right)$.

\section{Blood metabolites}

The effects of WDS on blood metabolites are shown in Table 7. There was a linear increase in the plasma concentrations of butyrate $(\mathrm{P}<0.10)$, glucose $(\mathrm{P}<0.10)$, NEFA $(\mathrm{P}<0.05)$ and urea $(\mathrm{P}<0.001)$ with increasing rate of WDS inclusion. The plasma insulin concentration of the first block of the four high producing cows was lower than the mean value for all other cows (26.0 vs. $30.3 \mathrm{mU} / \mathrm{l})$. Dietary effects on blood metabolites were similar in both blocks. The postprandial increases in plasma concentrations of propionate $(\mathrm{P}<0.05)$, butyrate $(\mathrm{P}<0.001)$, insulin $(\mathrm{P}<0.05)$ and urea $(\mathrm{P}<0.05)$ increased linearly with the level of WDS (Fig 1.). In other metabolites, the diet $\mathrm{x}$ sampling interaction did not reach statistical significance.

\section{Discussion}

Feed intake in response to WDS supplementation increased, in contrast to our earlier studies with DDS (Ala-SEPPÄLÄ et al. 1988; HuHTANEN et al. 1991). This was mainly because the intake of bar- ley on WDS0 diet was less than offered. However, among the WDS diets, the increase in silage and total DM intake suggests that the substitution rate of WDS is smaller than that of barley. The differences in the digestibility, though statistically significant, were trivial and too small to affect feed intake. As the amount of WDS in the diet increased, there was a linear decrease from 6.44 to $5.99 \mathrm{~kg} / \mathrm{d}$ $(\mathrm{P}<0.01)$ in NDF intake, suggesting that factors other than rumen fill were controlling the feed intake of WDS containing diets.

The response to WDS in milk yield was slightly greater than in the previous study with treated DDS (HUHTANEN et al. 1991), probably because of a greater increase in feed intake. The response in milk yield can be accounted for by increased supply of ME with the WDS diets, even though most of the extra energy had been partitioned towards body tissues. The mean response of $0.11 \mathrm{~kg}$ milk per $1 \mathrm{MJ}$ increase in $\mathrm{ME}$ is similar to that reported by GORDON (1984) for cows receiving increasing amounts of concentrate. None the less, the possible effects of treatment of WDS with the formaldehyde reagent can not be ruled out. Treatment of DDS with the same reagent tended to increase (HUHTANEN et al. 1991) and treatment of barley or oats increased milk yield (KASSEM et al. 1987;

Table 7. The concentrations of some blood and plasma metabolites in cows given the experimental diets.

\begin{tabular}{|c|c|c|c|c|c|c|c|c|}
\hline & \multicolumn{4}{|c|}{ Treatment } & \multirow{2}{*}{ SEM } & \multicolumn{3}{|c|}{ Significance of effect } \\
\hline & WDS0 & WDS1 & WDS2 & WDS3 & & Linear & Quadr. & Cubic \\
\hline Acetoacetate $(\mathrm{mmol} / \mathrm{l})$ & 0.155 & 0.138 & 0.119 & 0.121 & 0.0021 & NS & NS & NS \\
\hline B-hydroxybutyrate $(\mathrm{mmol} / \mathrm{l})$ & l) 1.37 & 1.18 & 1.13 & 1.09 & 0.0157 & NS & NS & NS \\
\hline \multicolumn{9}{|c|}{$\mathrm{VFA}(\mu \mathrm{mol} / 1)$} \\
\hline Acetate & 1079 & 985 & 1105 & 984 & 105.2 & NS & NS & NS \\
\hline Propionate & 22.2 & 28.0 & 30.9 & 27.4 & 3.51 & NS & NS & NS \\
\hline Isobutyrate & 6.6 & 7.7 & 8.1 & 7.2 & 0.89 & NS & NS & NS \\
\hline Butyrate & 42.9 & 52.3 & 53.4 & 54.4 & 4.03 & o & NS & NS \\
\hline Isovalerate & 4.6 & 5.0 & 5.0 & 5.0 & 0.59 & NS & NS & NS \\
\hline Glucose $(\mathrm{mmol} / \mathrm{l})$ & 3.35 & 3.46 & 3.56 & 3.55 & 0.080 & o & NS & NS \\
\hline Insulin $(\mathrm{mU} / \mathrm{l})^{1}$ & 27.9 & 30.9 & 32.7 & 29.7 & 1.79 & NS & NS & NS \\
\hline NEFA $(\mu \mathrm{mol} / 1)$ & 92 & 93 & 99 & 103 & 3.87 & * & NS & NS \\
\hline Urea $(\mathrm{mmol} / \mathrm{l})$ & 3.58 & 3.86 & 4.72 & 5.08 & 0.214 & $* * *$ & NS & NS \\
\hline
\end{tabular}

'The biological activity of the bovine insulin standards used was approximately $27 \mathrm{IU} / \mathrm{mg}$ 

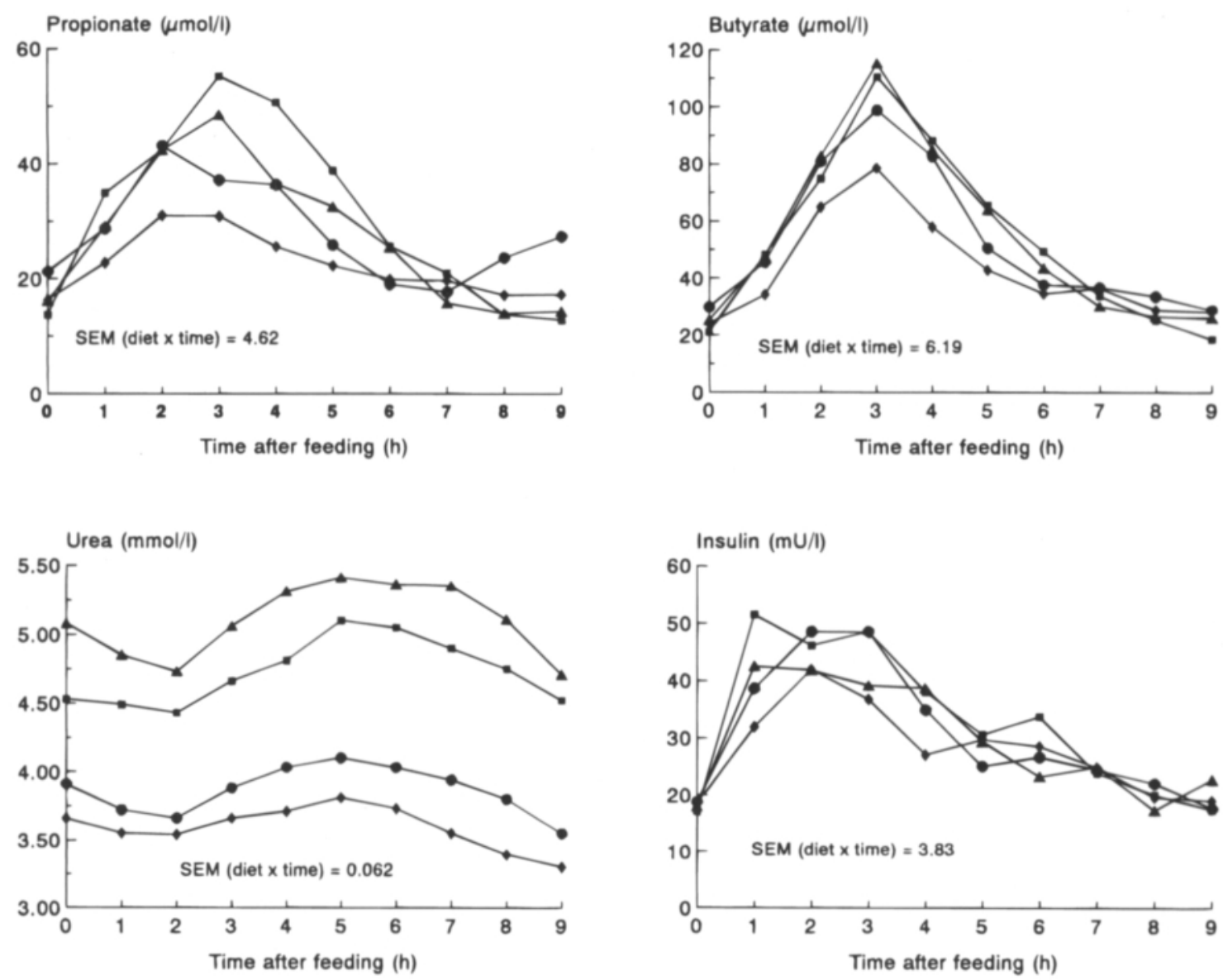

Fig. 1. The postprandial changes in plasma propionate, butyrate, urea and insulin concentration ( $\bullet$ WDS0,

- WDS2 and $\boldsymbol{\Delta}$ WDS3).

MARTIN and ThOMAS 1988). However, it should be noted that in the latter studies the rate of application of the reagent on a crude protein basis was $4-5$ times greater than in the present study.

There were differences in the response to WDS in the yield of milk constituents indicating corresponding changes in the precursor ratio (OLDHAM and EMmans 1988). Fat yield was unaffected, protein yield was moderately increased and the greatest increase occurred in lactose yield. Enhanced lactose yield with increasing rate of WDS inclusion was due to increases both in milk yield and lactose content. Assuming $47 \mathrm{~g} / \mathrm{kg}$ lactose in milk, the $64 \mathrm{~g}$ of lactose/d increase with diet WDS3 corresponded to about $1.4 \mathrm{~kg}$ milk, which is greater than the observed $0.8-0.9 \mathrm{~kg} / \mathrm{d}$ improvements in actual milk yield with the WDS diets. Thus it appears that WDS provides the cows with a mixture of nutrients which favours especially lactose synthesis. In cattle fed a grass silage-based diet, replacing either barley or barley fibre with untreated WDS increased the molar proportion of propionate in rumen VFA mainly at the expense of acetate (HUHTANEN 1992), probably as a result of lactate fermentation (CHAMBERLAIN et al. 1983; JAAKKOLA and HUHTANEN 1992). Enhanced ruminal propionate production increases the supply of glucose precursors to the liver and hepatic gluconeogenesis. Since glucose is 
the main substrate for lactose synthesis (KUHN 1983), and milk yield is largely determined by lactose secretion (SuTTON 1989), greater milk yield with WDS diets may be explained by enhanced supply of lactose precursors. The lower milk lactose content with diets favouring low propionate to butyrate ration in rumen VFA (WDS0) is consistent with our rumen VFA infusion studies, which demonstrated a decrease in lactose content with decreasing propionate to butyrate ratio.

The response to WDS in milk protein yield may be explained by an increased supply of amino acids. However, a replacement of barley or barley fibre with untreated WDS did not affect duodenal NAN flow suggesting that all extra $\mathrm{N}$ from WDS was absorbed as ammonia from the rumen (HUHTANEN 1992). Neither any effects on ammonia production in vitro were detected with the level of formaldehyde used in the present study, and the rate of application had to be three times greater to reduce the rate of ammonia production (KUKKONEN and HuHTANEN, unpublished). These observations suggest that the response to WDS in protein yield may, at least partially, be due to increased ruminal propionate production which reduces the use of amino acids in gluconeogenesis (ARMSTRONG 1982).

Although including WDS in the diet might be expected to reduce milk fat content as a result of changes in the rumen fermentation pattern (HUHTANEN 1992), the changes observed were small and statistically not significant. Typically characteristic of grass silage-barley diets (THOMAs and СНАMBERLAIN 1982), the proportion of butyrate remained high when barley was partially replaced with WDS (HUHTANEN 1992). This suggests that milk fat content may not be reduced by moderate changes in the ratio of acetate to propionate when the proportion of butyrate is high.

Live weight change tended to decrease with increasing level of WDS, in agreement with ALASEPPÄLÄ et al. (1988) and HuHTANEN et al. (1991). Differences in the concentrations of most of the blood metabolites and milk acetone do not, however, indicate increased mobilization of body tissues with the level of WDS, rather the reverse.
There may be considerable errors in estimating live weight change, especially in change-over experiments, and the differences may be related to the changes in gut fill rather than in actual energy balance. Smaller live weight gain in cows receiving diets containing distiller's solubles are probably related to a smaller rumen volume (HUHTANEN 1992).

Similar effects of distiller's solubles on calculated utilization of ME were observed in our previous studies (ALA-SEPPÄLÄ et al. 1988; HUHTANEN et al. 1991). Decreasing efficiency of ME utilization for lactation with increasing level of WDS could be related to the above mentioned difficulties in estimating energy balance from live weight change. The energy cost of synthesizing and excreting the surplus nitrogen as urea can also account for part of the difference (see OldHam 1984).

Although replacing barley with WDS in the concentrate has been found to decrease the concentration and proportion of acetate and increase those of propionate in the rumen fluid of cattle (HUHTANEN 1992), in the present study the rate of WDS inclusion did not significantly affect the average plasma concentrations of acetate or propionate (Table 7). However, a large increase in the postprandial peak of propionate with WDS diets (Fig. 1) may indicate an increased ruminal propionate production from enhanced lactate intake (СHAMBERLAIN et al. 1983; JAAKKOLA and HUHTANEN 1992). Lactate intake increased from $475 \mathrm{~g} / \mathrm{d}$ to 884 $\mathrm{g} / \mathrm{d}$ as the rate of WDS inclusion increased from 0 to $3 \mathrm{~kg} \mathrm{DM} / \mathrm{d}$.

The increase in the mean concentration of plasma glucose with WDS diets is most likely caused by the increased supply of glucogenic precursors, propionate and amino acids, from the digestive tract to the liver (BROCKMAN, 1986). The increase in gluconeogenesis with WDS diets is further supported by higher lactose content and yield as compared with the barley diet. The decrease in plasma glucose concentration by intravenous infusion of insulin has also been shown to reduce milk lactose content and yield (THOMAs et al. 1987).

According to the glucogenic theory (MCCLY- 
MOND and WALLACE 1962), the increased absorption of propionate increases the hepatic glucose production and insulin secretion. In agreement with this, the postprandial peak in plasma propionate was increased with the WDS diets, and the change in the mean plasma insulin concentrations was parallel with the changes in the mean concentrations of plasma propionate and glucose. The glucogenic theory is further supported by the slightly lower milk fat content with WDS diets compared to the control diet. However, the possible effect of butyrate on plasma insulin (MANNS et al. 1967) can not be ruled out. Of plasma VFA, butyrate had the highest positive correlation with insulin during the postprandial period (eg. $3 \mathrm{~h}$ after feeding $\mathrm{r}=0.536$; $\mathrm{P}<0.01$ ).

The increase in plasma NEFA concentration may indicate a greater tissue mobilization in cows given increasing amounts of WDS or may be a consequence of the enhanced supply of dietary fat (770 $\mathrm{g} / \mathrm{d}$ for diet WDS0 and $870 \mathrm{~g} / \mathrm{d}$ for diet WDS3) (GIESECKE 1983). The changes, although nonsignificant, in the concentrations of blood ketones and plasma insulin supports the latter.

In the present study, the concentration of plasma butyrate was higher than that reported by SUTTON et al. (1986) and HuHTANEN et al. (1992). This may be related to the basal diet of restrictively fermented silage and barley, which is known to produce a butyrate type rumen fermentation (HUHTANEN $1988 ; 1992)$. The increase in the plasma butyrate concentration with increasing amount of WDS in the diet indicates either an increased postprandial absorption of butyrate from the rumen (STERN et al. 1970; de JONG 1982; HUHTANEN et al. 1992) or dif- ferences in the conversion of butyrate to BHB both in the rumen epithelium and liver. The ratio of plasma butyrate to blood BHB increased with the level of WDS in the diet from 0.031 to 0.050 , indicating a decreased conversion of butyrate to BHB in the rumen epithelium or in the liver. The blood concentration of ketones decreased slightly with increasing amount of WDS in the diet. This suggests that either BHB was cleared more rapidly or that ketogenesis decreased when glucose availability increased in relation to energy requirements (AmARAL et al. 1990). Similarly, ØrSKOV and MACLEOD (1990) reported that an increase in blood glucose concentration with decreased blood $\mathrm{BHB}$ concentration.

The increased intake of protein was the obvious reason for the increased plasma urea concentration with increasing rate of WDS inclusion in the diet (OltNer and WiKTORSSON 1983; Ropstad et al. 1989; Clement et al. 1991), which indicates inefficient use of extra protein supplied by WDS. The concentration of urea in milk also increased with the level of WDS in the diet, although the relative increase of urea was much smaller in milk than in plasma.

It is concluded that the substitution of barley with WDS increased yields of milk, protein and lactose. This may be due to greater absorption of glucogenic precursors from the digestive tract and increased hepatic gluconeogenesis.

Acknowledgements. The authors express their appreciation to Ms. Marjatta Jokela for techical assistance, to the barn crew for the care of the animals and the laboratory staff for chemical analyses. This study was supported by Alko Ltd.

\section{References}

Ala-Seppälä, H., Huhtanen, P. \& NÃsı, M. 1988. Silage intake and milk production in cows given barley or barley fibre with or without distillers solubles. J. Agric. Sci. Finl. 60: 723-733.

Amaral, D.M., Veenhuizen, J.J., Drackely, J.K., Cooley, M.H., MCGilliard, A.D \& Young, J.W. 1990. Metabolism of propionate, glucose and carbon dioxide as affected by exogenous glucose in dairy cows at energy equilibrium. J. Dairy Sci. 73: 1244-1254.

ANNISON, E.F., BiCKeRSTAFFE, R. \& LiNZELL, J.L. 1974. Glucose and fatty acid metabolism in cows producing milk of low fat content. J. Agric. Sci. Camb. 82: 87.

ARC 1980. The nutrient requirements of Ruminant Livestock. Agricultural Research Council. Commonwealth Agricultural Bureaux, Slough.

ARMSTRONG, D.G. 1982. Dietary protein and the high- 
yielding dairy cow. $12^{\text {th }}$ Hannah Lecture. Report, Hannah Research Institute, p. 65-74.

BINES, J.A. \& HART, I.C. 1984. The response of plasma insulin and other hormones to intraruminal infusion of VFA mixtures in cattle. Can. J. Anim. Sci. 64 (Suppl.): 304305.

Brockman, R.P. 1986. Pancreatic and adrenal hormonal regulation of metabolism. In: Milligan, L.P. et al. (eds.). Control of Digestion and Metabolism in Ruminants. Prentice-Hall, Englewood Cliffs, N.J., p. 405-419.

Chamberlain, D.G., Thomas, P.C. \& Anderson, F.I. 1983. Volatile fatty acid proportions and lactic acid metabolism in the ruminant in sheep and cattle receiving silage diets. J. Agric. Sci. Camb. 101: 47-58.

-, MARTIn, P.A. \& Robertson, S. 1989. Optimizing compound feed use in dairy cows with high intakes of silage. In: Haresign, W. \& Cole, D.J.A. (eds.). Recent Advances in Animal Nutrition. Butterworths. p. 175-193.

Clement, C., Jans, F. \& Blum, J. 1991. Hormones and metabolites in lactating dairy cows fed insufficient amounts of protein. J. Anim. Physiol. Anim. Nutr., 65 :244-253.

European Patent Office 1982. Additive composition of animal feedingstuffs. European patent application No 0 043202 .

GIESECKE, D. 1983. Plasma free fatty acids. In: Riis, P.M. (ed.). Dynamic Biochemistry of Animal Production. Elsevier, p. 197-212.

Gordon, F.J. 1984. The effect of the level of concentrate supplementation with grass silage during the winter on the total lactation performance of dairy cows. J. Agric. Sci. Camb. 102: 163-179.

HuhtANEN, P. 1988. The effects of barley, unmolassed beet pulp and molasses supplements on organic matter, nitrogen and fibre digestion in the rumen of cattle given silage diet. Anim. Feed Sci. Technol. 20: 259-278.

- 1992. The effects of barley vs barley fibre with or without distiller's solubles on site and extent of nutrient digestion in cattle fed grass silage based diet. Anim. Feed Sci. Technol. 36: 319-337.

-, AlA-SEPpÃLÃ, H. \& NÃsı, M. 1988. Response of silage intake and milk production to replacement of barley by barley fibre derived from integrated starch-ethanol process. J. Agric. Sci. Finl. 60: 711-721.

—, Khalilı, H. \& NÄSI, M. 1991. A comparison of barley distiller's solubles in untreated or formaldehyde treated forms and rapeseed meal as protein supplements in dairy cows given grass silage ad libitum. J. Agric. Sci. Finl. 63: 455-463.

-, Miettinen, H. \& Ylinen, M. 1992. Effect of ruminal butyrate on milk production and blood constituents in lactating dairy cows fed grass silage-based diet. Submitted for publication.

JAAKKola, S. \& Huhtanen, P. 1989. The effect of lactic acid on the microbial protein synthesis in the rumen of cattle. Asian Australian J. Anim. Sci. 2: 398-399.
— \& Huhtanen, P. 1992. Rumen fermentation and microbial protein synthesis in cattle given increasing levels of lactic acid with grass silage based diets. J. Agric. Sci. Camb. (In press).

JennY, B.F. \& Polan, C.E. 1975. Postprandial blood glucose and insulin in cows fed high grain. J. Dairy Sci. 58: 512-514.

de JoNG, A., 1982. Patterns of plasma concentrations of insulin and glucagon after intravascular and intraruminal administration of volatile fatty acids in the goat. $\mathbf{J}$. Endocr. 92: 357-370.

Kassem, M.M., Thomas, P.C. \& Chamberlain, D.G. 1987. Silage intake and milk production in cows given barley supplements of reduced rumen degradability. Grass Forage Sci. 42: 175-183.

KunN, N.J. 1983. The biosynthesis of lactose. In: Mepham, T.B. (ed.). Biochemistry of Lactation, p. 159-176.

MAFF 1984. Energy Allowances and Feeding Systems for Ruminants. Ministry of Agriculture, Food and Fisheries. Bulletin 43. London, HMSO.

Manns, J.G., BodA, J.M. \& Willes, R.F. 1967. Probable role of propionate and butyrate in control of insulin secretion in sheep. Am. J. Physiol. 212: 756-764.

MarTin, P.A. \& ThOMAS, P.C. 1988. Dietary manipulation of yield and composition of milk: Effects of dietary inclusions of barley and oats in untreated or formaldehyde-treated forms on milk fatty acid composition. J. Sci. Food Agric. 43: 145-154.

McClymont, G.L. \& Vallance, S. 1962. Depression of blood glycerides and milk fat synthesis by glucose infusion. Proc. Nutr. Soc. 21: xli

Miettinen, H. \& Huhtanen, P. 1989. The concentrations of blood metabolites and the relations between blood parameters, fatty acid composition of milk and estimated ME-balance in dairy cows given grass silage ad libitum with five different carbohydrate supplements. Acta Agric. Scand. 39: 319-330.

Newbold, C.J., Chamberlain, D.G. \& Williams, A.G. 1986. The effects of defaunation on the metabolism of lactic acid in the rumen. J. Sci. Food Agric. 37: 10831090.

NÄsı, M. 1988. Evaluation barley feed fractions from integrated ethanol-starch production in diets of ruminants. J. Agric. Sci. Finl. 60: 701-709.

OLDHAM, J.D. 1984. Protein-energy relationship in dairy cows. J. Dairy Sci. 67: 1090-1114.

- \& Emmans, G.C. 1989. Prediction of responses to required nutrients in dairy cows. J. Dairy Sci. 72: 3212 3229.

OLtNER, R. \& WiKTORSSON, H. 1983. Urea concentration in milk and blood as influenced by feeding varying amounts of protein and energy to dairy cows. Livestock. Prod. Sci. 10: 457-467.

Ørskov, E.R. \& MACLeOD, N.A., 1990. Dietary-induced thermogenesis and feed evaluation in ruminants. Proc. Nutr. Soc. 49: 227-237. 
RAJAMÄKI, S. \& RAURAMAA, A. 1984. The automated determination of urea in milk. Finn. Chem. Lett. 2: 47-48.

— \& RAURAMAA, A. 1985. The determination of acetoacetate and 3-hydroxybutyrate in milk. Finn. J. Dairy Sci. XLIII, 1: 9-15.

ROBERTS, D.J. 1987. The effect of feeding fodder beet to dairy cows offered grass silage ad libitum. Grass Forage Sci. 42: 391-396.

Ropstad, E., VIK-Mo, L. \& ReFSDAL, A.O. 1989. Levels of milk urea, plasma constituents and rumen liquid ammonia in relation to the feeding of dairy cows during early lactation. Acta Vet. Scand. 30: 199-208.

Snedecor, G.W. \& Cochran, W.C., 1967. Statistical Methods. 6th Ed. Iowa State Univ. Press, Ames, IA, p. 593.

Stern, J.S., BAILE, C.A. \& MAYER, J., 1970. Are propionate and butyrate physiological regulators of plasma insulin in ruminants? Am. J. Physiol. 219: 84-91.

SutTON, J.D. 1989. Alteration of milk composition by feeding. J. Dairy Sci 72, Suppl. 1: 152 (Abstr.)

-, Hart, I.C.,Broster, W.H., Elliott, J.R. \& Schuller, E. 1986. Feeding frequency for lactating cows: effects on rumen fermentation and blood metabolites and hormones. Br. J. Nutr. 56: 181-192.

Thomas, C. \& RAE, R.C. 1988. Concentrate supplementation of silage for dairy cows. In: Garnsworthy, P.C. (ed.). Nutrition and Lactation in the Dairy Cow. Butterworths. p. 327-354.

— \& ChAmberlain, D.G. 1982. Silage as a foodstuff. In: Rook, J.A.F. \& Thomas, P.C. (eds.). Silage for Milk Production. National Institute for Research in Dairying/Hannah Research Institute. p. 63-101.

-, Chamberlain, D.G., Martin, P.A. \& Robertson, S. 1987. Dietary energy intake and milk yield and composition in dairy cows. In: Moe, P.W. et al. (eds.). Energy Metabolism of Farm Animals. EAAP Publ. No. 32. p. 18-21.

TYRREL, H.F. \& REID, R.A. 1965. Prediction of energy vale of cow's milk. J. Dairy Sci. 48: 1215-1223.

Van Keulen, J. \& Young, B.A. 1977. Acid insoluble ash as a natural marker for digestibility studies. J. Anim. Sci. 44: 282-287.

\section{Manuscript received March 1992}

Pekka Huhtanen

University of Helsinki

Department of Animal Science

SF-00710 Helsinki, Finland

Harri Miettinen

Valio, Research and Development Centre

Box 176

SF-00181 Helsinki, Finland

\title{
SELOSTUS
}

\section{Tärkkelysrankin vaikutus maidontuotantoon ja veren metaboliitteihin lypsylehmillä säilörehuun perustuvalla ruokinnalla}

\author{
Pekka Huhtanen ja Harri Miettinen \\ Helsingin yliopisto ja Valion tutkimus- ja tuotekehityskeskus
}

Tuoreen tärkkelysrankin vaikutuksia rehun syöntiin ja sulavuuteen, maidontuotantoon ja verimetaboliitteihin tutkittiin 12 ay-rotuisella lehmällä tasapainotetun latinalaisen neliön mukaan tehdyssä kokeessa. Lehmät saivat säilörehua vapaasti ja litistettyä ohraa $9 \mathrm{~kg} / \mathrm{pv}$, jonka kuiva-aineesta 0 (TR0), 1 (TR1), 2 (TR2) ja 3 kg (TR3) korvattiin tuoreen tärkkelysrankin kuiva-aineella. Tärkkelysrankki paransi văkirehun maittavuutta, minkä tuloksena säilörehun syönti vaihteli käyräviivaisesti $(\mathrm{P}<0.05)$ rankkitason mukaan ollen pienin TR1-ruokinnalla. Kuiva-aineen syönti $(\mathrm{P}<0.05)$, maitotuotos $(\mathrm{P}<0.05)$ ja laktoosituotos $(\mathrm{P}<0.01)$ lisääntyivăt lineaarisesti rankkimäärän lisääntyessä. Rankkimäärän kasvaessa valkuaistuotos lisääntyi sekä lineaarisesti $(\mathrm{P}<0.05)$ että käyräviivaisesti $(\mathrm{P}<0.05)$ saavuttaen maksiminsa TR2ruokinnalla. Rankilla ei ollut merkitsevää vaikutusta maidon rasva- tai valkuaispitoisuuteen, mutta laktoosipitoisuus nousi $(\mathrm{P}<0.01)$ rankkimäärän lisăäntyessă. Ohran asteittainen korvaaminen rankilla lisäsi plasman glukoosi- $(\mathrm{P}<0.10)$, voihappo- $(\mathrm{P}<0.10)$, urea- $(\mathrm{P}<0.001)$ ja vapaiden rasvahappojen $(\mathrm{P}<0.05)$ pitoisuutta. Ruokinnan jälkeiset maksimit plasman propionihappo-, voihappo-, insuliini- ja ureapitoisuudessa lisääntyivät rankkitason lisääntyessä. Vastaavasti veren ketoaineiden pitoisuudet ruokinnan jälkeen vähenivăt. Veriplasman metaboliiittien keskimääräisten pitoisuuksien ja ruokinnan jälkeisten muutosten perusteella arvioituna rankki näyttäisi lisäävän maksan glukoneogeneesiä ja ureasynteesiä. Lisăäntynyt glukoosin tuotanto on todenäköisesti peräisin pötsin lisääntyneestä propionihapon tuotannosta rankin sisăltämän maitohapon käydessä păäasiassa propionihapoksi. Muutokset maidon koostumuksessa ja maidon komponenttien suhteellisissa tuotoksissa tukevat näitä johtopäätöksiä. 